\title{
Nicos Poulantzas on political economy, political ecology, and democratic socialism
}

\author{
Bob Jessop ${ }^{1}$ \\ Lancaster University, UK
}

\begin{abstract}
This article presents the inaugural memorial lecture at the Nicos Poulantzas Institute in Athens. It examines and extends the work of the eponymous Greek legal and political theorist, political economist, and communist intellectual, Nicos Poulantzas, who radically transformed Marxist state theory, made major contributions to the critique of political economy for the era of Atlantic Fordism and post-war American imperialism, and called for a judicious balance between representative and direct democracy to secure a democratic transition to democratic socialism. It first offers some general reflections on the originality, legacy and actuality of Poulantzas's work in these respects and then reconstructs his later views on the critique of political economy before his death in 1979. Noting his neglect of the environment and issues of political ecology, which was typical of the French and Greek left in the 1970s and also rooted in more general features of Marxist theorizing on nature and the environment, the article elaborates a Poulantzasian view of political ecology based on key arguments from his work. The article concludes by reasserting the validity of his vision of democratic socialism, indicating that it would have become a critique of political ecology, and suggests that he would have approached this in the same spirit of romantic public irony that was advocated by one of his major theoretical and political influences - Antonio Gramsci.

Key words: capitalist states; class analysis; democracy; ecology; imperialist rivalries; Nicos Poulantzas; productivism; state theory; the strategic-relational approach
\end{abstract}

\section{Résumé}

Cet article présente la première conférence commémorative à l'Institut Nicos Poulantzas à Athènes. Il examine et étend le travail du théoricien juridique et politique grec, Nicos Poulantzas, économiste politique et intellectuel communiste, qui a radicalement transformé la théorie de l'Etat marxiste et apporté une contribution majeure à la critique de l'économie politique pour l'ère du fordisme atlantique. Il réclame un équilibre judicieux entre démocratie représentative et démocratie directe pour assurer une transition démocratique vers le socialisme démocratique. J'offre quelques réflexions générales sur l'originalité, l'héritage et l'actualité de l'œuvre de Poulantzas à cet égard, puis reconstruit ses vues ultérieures sur la critique de l'économie politique avant sa mort en 1979. L'article élabore une vision poulantzasienne de l'écologie politique fondée sur des arguments clés De son travail. Il note sa négligence par rapport à l'environnement naturel et les questions d'écologie politique, typiques de la gauche française et grecque dans les années 1970, et visible dans la théorie marxiste sur la nature et l'environnement. L'article conclut en réaffirmant la validité de sa vision du socialisme démocratique, indiquant qu'il serait devenu une critique de l'écologie politique, et suggère qu'il aurait abordé cela dans le même esprit d'ironie romantique et publique qui a été préconisé par l'un de ses grandes influences théoriques et politiques - Antonio Gramsci.

Mots clés: états capitalistes; analyse de classe; la démocratie; écologie; rivalités impérialistes; Nicos Poulantzas; productivisme; théorie des états; l'approche stratégique-relationnelle

\section{Resumen}

Este artículo presenta la conferencia inaugural conmemorativa en el Nicos Poulantzas Institute en Atenas. Aquí se examina y profundiza el trabajo del epónimo griego, Nicos Poulantzas, quien transformó radicalmente la teoría marxista del estado. El teórico político y legal, economista político, e intelectual comunista hizo grandes contribuciones a la crítica de la economía política para la era del Fordismo Atlántico

\footnotetext{
${ }^{1}$ Dr Bob Jessop, Distinguished Professor of Sociology, Department of Sociology, Lancaster University, UK. Email: b.jessop "at" lancaster.ac.uk. This was the First Annual Nicos Poulantzas Memorial Lecture, organized by the Nicos Poulantzas Institute, delivered at Panteion University of Economics and Political Sciences, Athens, 7th December 2007, and lightly revised in February 2017.
} 
y el imperialismo estadounidense de la post-guerra, y convocó a un acertado balance entre la democracia representativa y la democracia directa para asegurar una transición democrática hacia el socialismo democrático. Este artículo ofrece, primeramente, reflexiones generales sobre la originalidad, legado y actualidad del trabajo de Poulantzas en estos temas, para luego reconstruir sus posteriores acercamientos a la crítica de la economía política antes de su muerte en 1979. Notando su falta de atención en el medio ambiente y asuntos de ecología política, típicos de las izquierdas francesa y griega de los años setenta, y apegado a aspectos generales de la teorización marxista de la naturaleza y el medio ambiente, este artículo elabora una perspectiva poulantziana de ecología política con base en los principales argumentos de su trabajo. El artículo concluye reiterando la validez de su visión del socialismo democrático, indicando que se habría vuelto una crítica de ecología política, y sugiere que Poulantzas se habría aproximado con el mismo espíritu de ironía pública romántica que fue promovida por una de sus mayores influencias teóricas y políticas - Antonio Gramsci.

Palabras clave: Estados capitalistas, análisis de clase, democracia, ecología, rivalidades imperialistas, Nicos Poulantzas, productivismo, teoría del estado, enfoque estratégico-relacional.

\section{$\pi \varepsilon \rho i ́ \lambda \eta \psi \eta$}

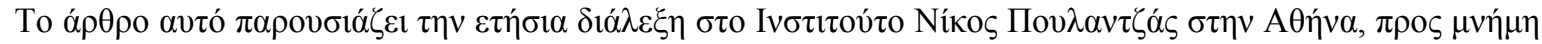

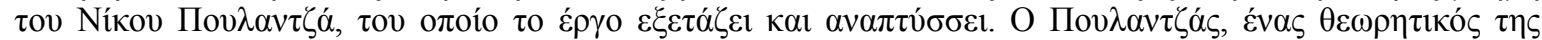

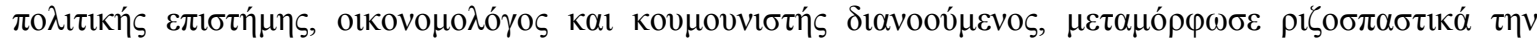

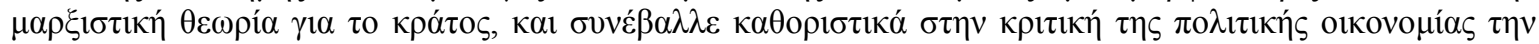

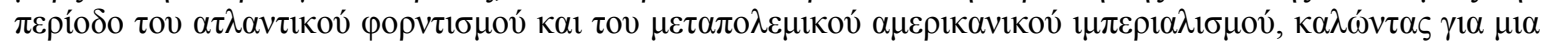

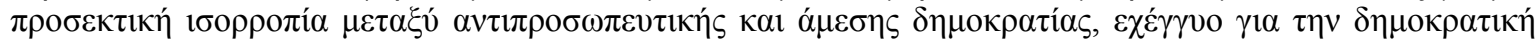

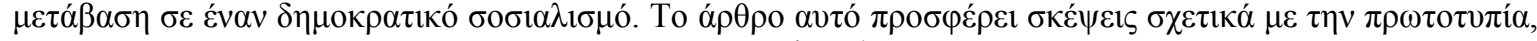

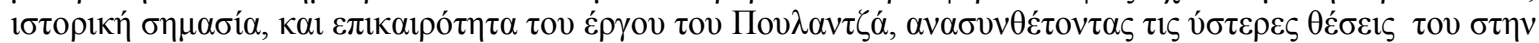

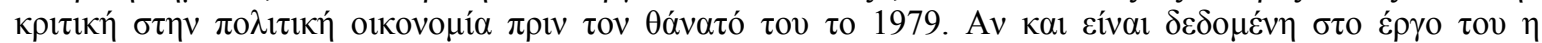

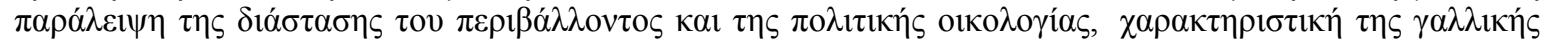

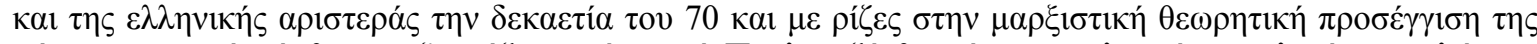

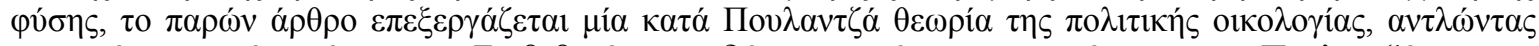

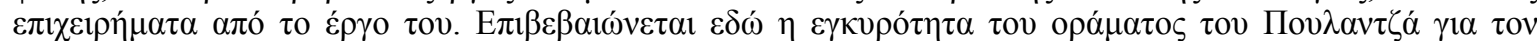

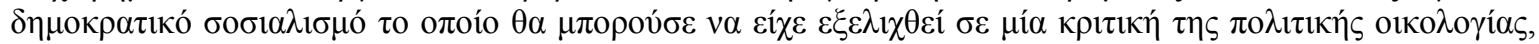

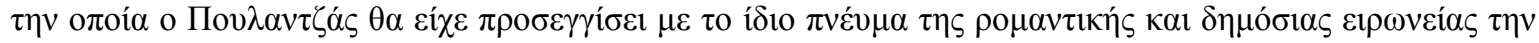

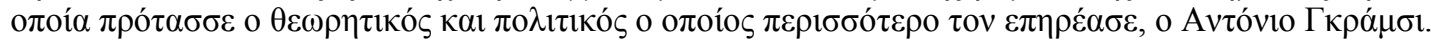

\section{Introduction}

All twentieth-century political theory has basically posed the same question: what is the relationship between the State, power and social classes? ... If all political theory and all theories of socialism (including Marxism) revolve around this question, this is because it constitutes a real problem. ... It also involves the question of the transformation of the State in the transition to democratic socialism. (Poulantzas 1978a: 11,14)

It is a real honour and gives me great personal pleasure to deliver the first Annual Nicos Poulantzas Memorial Lecture in Athens tonight. Although I met Nicos Poulantzas only once, towards the end of his life, his impact on my intellectual development has been immense and is matched only by the influence of Karl Marx and Antonio Gramsci. It is reflected in what I have taken from him and, I hope, taken further; as well as in where I have disagreed with him and even moved away from his positions. Delivering this lecture is therefore an opportunity to repay some of that intellectual debt and to demonstrate that a theorist continues to live as long as his or her work continues to be debated. I am happy to note in this regard an exciting and productive Poulantzas revival as issues that he identified in the 1970s are once more being put on the theoretical and political agenda in the first decades of the $21^{\text {st }}$ century.

This revival is reflected in two of the three themes of my lecture title - political economy and democratic socialism. The third theme - linking the other two - is political ecology. I want to argue that, 
without a proper engagement with political ecology, we cannot consolidate Poulantzas's lessons about political economy and the democratic transition to democratic socialism. Accordingly, my memorial lecture has four main sections:

(1) some general reflections on the originality, legacy and actuality of Poulantzas's work;

(2) a re-appropriation of his critique of political economy;

(3) a discussion of his neglect of the environment and issues of political ecology; and

(4) a reassertion of the validity of his vision of the democratic transition to democratic socialism.

\section{Why Poulantzas still matters}

More than two decades ago, in my intellectual biography of Poulantzas, I described him as the most important Marxist political theorist of the postwar period (Jessop 1985). Tonight, I want both to reaffirm and to qualify this view by arguing that his studies should be seen nowadays as "classical" rather than "contemporary." This useful distinction derives from Niklas Luhmann, who suggests that a theory is "classical" when it offers an interconnected set of claims that has been superseded by later theoretical developments and is, therefore, no longer convincing in its original form. Yet it still survives as a challenge, desideratum, or problem on a theoretical level as long as its way of posing problems can still be accepted. This implies that its authoritative character is ambivalent: one can infer from such a theory what must be achieved, but no longer how to achieve it (Luhmann 1982: 4).

This is a fair description of the status of Poulantzas's work in the 21st century and would certainly not have surprised this great thinker. For, as he noted in State, power, socialism, "[t]he theory of the capitalist State cannot be isolated from the history of its constitution and reproduction" (1978a: 25, italics in original). Hence, as capitalism continues to change, the theory of the capitalist state must be revised to reflect those changes. Yet the revolutionary approach to the capitalist state that he developed in his later work still provides the best starting point for these revisions. I have already shown this for the updating of Poulantzas's seminal analysis of Internationalization of capitalist relations and the nation-state $(1974,1975)$ in my paper on Globalization and the national state (2002). Now I want to begin the same task for Poulantzas's more general arguments, sadly neglected compared with his state theory, on the critique of political economy. But first let me review the originality, legacy, and actuality of his work considered in the round.

Poulantzas's intellectual career began with studies in Marxist legal philosophy and legal theory that were inspired by Sartrean existentialism; he then turned to political theory and began to develop a view of the capitalist type of state and political struggle that owed much to Gramsci. This approach was soon integrated into a broader perspective on the state in capitalist societies influenced (not always to the good) by the structural Marxism of Louis Althusser and Étienne Balibar. Soon afterwards, he began a slow retreat from the immobilizing implications of this kind of structuralism and showed increasing concern with strategically relevant theoretical issues - such as the nature of fascism and military dictatorships, the changing contours of imperialism and social class relations, and the role of parties and social movements in modern capitalism. In his final studies, he increasingly addressed problems posed by the self-evident crisis in Marxism as social theory and as a guide to practice - taking on board some of the arguments about power advanced by Michel Foucault and tackling some key issues concerning socialism and the democratic transition to democratic socialism. Notwithstanding these many and varied concerns, his major theoretical contribution was to develop a view of state power as a social relation that is reproduced in and through the interplay between the state's institutional form and the changing balance of political forces.

Poulantzas's significance resides in the fact that he was almost alone among postwar Marxists to address and answer the really crucial questions within Marxist politics. These questions can be inferred from a critique of Western Marxism by Perry Anderson, one of its leading Anglophone exponents. Anderson argues that Western Marxism failed to answer the following key questions: 
- What is the real nature and structure of bourgeois democracy as a type of State system, that has become the normal mode of capitalist power in the advanced countries?

- What type of revolutionary strategy is capable of overthrowing this historical form of State - so distinct from that of Tsarist Russia?

- What would be the institutional forms of socialist democracy in the West, beyond it?

And he added that Marxist theory has scarcely touched these three subjects in their interconnection (Anderson 1976: 103).

Yet these three subjects preoccupied Poulantzas from 1964 until his death in 1979. His first influential book, Political power and social classes (1968), explored the real nature and structure of bourgeois democracy. Fascism and dictatorship (1970) dealt with the nature of fascist regimes and the failure of organized labour either to check their rise or to overthrow them. It was also directly concerned with the distinction between the "normal mode of capitalist power in the advanced countries" and various "exceptional" modes of bourgeois political domination. In his third and fourth books, Classes in contemporary capitalism (1974) and Crisis of the dictatorships (1976), Poulantzas related problems of revolutionary strategy to democratic and exceptional regimes in both advanced and dependent capitalist countries. And his final book, State, power, socialism (1978a) reviewed contemporary threats to bourgeois democracy and the institutional forms that socialist democracy might assume in the West. Moreover, not only did Poulantzas tackle each of these topics, he also explored them in "their interconnection."

Poulantzas also addressed other important issues in Marxist theory. Anderson is a useful guide here too when he mentions four other failures. Contemporary Marxism had not tackled the meaning and position of the nation as a social unit and its relationship to nationalism. It had ignored the contemporary laws of motion of capitalism as a mode of production and the forms of crisis specific to these laws. It had neglected the true configuration of imperialism as an international system of economic and political domination. And it had not explored the nature of the bureaucratic states that developed in those backward countries where socialist revolutions had occurred. Poulantzas confronted all these issues too. He was particularly concerned with contemporary imperialism as well as with the political economy of modern capitalism. ${ }^{2}$ He also touched on the nation and nationalism, especially in State, power, socialism, and on the problems of bureaucratic socialism and Stalinism. In short, he was an unusual Western Marxist.

But what drove Poulantzas towards his eventual left-wing Eurocommunist position? The key appears to be his involvement in Greek and French politics. For Greece, his principal concern was to understand its military dictatorship, the conditions leading to the latter's overthrow, the prospects for moving from an antidictatorial alliance to an anti-imperialist, anti-monopoly alliance, and the absence of working class hegemony in the democratization process. The two key turning points for him were, first, the Greek coup in April 1967 - which put the significance of the distinction between democracy and dictatorship on the agenda at exactly the same time as he was describing the bourgeois democratic state as the most adequate form of capitalist state for securing bourgeois hegemony; and, second, its eventual collapse, against most left-wing expectations, under the weight of its own internal contradictions in May 1974. The manner of its collapse, especially the absence of mass struggles directly concerned to confront the state, confirmed Poulantzas in his rapidly growing suspicion that the state was far from monolithic and that class struggle penetrated deep within the state itself. In turn, this implied that a left Eurocommunist strategy aimed at intensifying the contradictions internal to the state as well as mobilizing the popular masses outside the state could prepare the ground for the eventual democratic transformation of the state system in its inclusive sense and its mobilization in support of even broader democratic socialist changes.

A further important influence was the break-up of the Union de la Gauche at the instigation of the French Communist Party in 1977, the subsequent decline in cooperation between socialists and communists in various spheres at different scales, and deterioration in the overall position of the left parties in France in

\footnotetext{
${ }^{2}$ On this topic, see Jessop (2017).
} 
1978-1979 (and, indeed, beyond). ${ }^{3}$ This prompted Poulantzas to lose faith in the leading role of vanguard communist parties and in proletarian struggles as the primary motor force of revolutionary transformation; and to turn towards a more complex - but also more problematic - alliance strategy. This should not only be pluri-classiste but also pluripartiste and, as such, it denied any a priori privilege to the working class or communist party. It emphasized the autonomous role of non-class forces and social movements in the struggle for democratic socialism. Indeed, Poulantzas began to value the contributions of popular-democratic struggles and of cross-class "new social movements" to a democratic transition to democratic socialism. This view was reinforced by the turbulence and eventual failure of the "Carnation Revolution" in Portugal (April 1974 to November 1975 and beyond), a process that occurred despite the more favourable position held by left-wing forces in the initial struggle for power. In this regard, Poulantzas was particularly scathing about the Portuguese reformists' focus on infiltrating the leading personnel of the state at the expense of conducting mass struggle and about the ultra-left's misguided beliefs that socialism had arrived, with the result that the state would simply wither away and could therefore be safely ignored. He called instead for a strategy that would democratize the state so that it could be used to defend autonomous rank-and-file movements operating at a distance from the state. Such a strategy, which was developed in discussions, interviews, and journalism, in a long essay on the crisis of the state (1976) and in his last two books, would also, he claimed, help the left to avoid the sort of statist degeneration of socialism that had occurred in the Soviet bloc.

\section{Poulantzas's contributions to the critique of political economy}

Poulantzas's early work showed little interest in the nature and dynamics of capital accumulation. In Political power and social classes (1973), he justified this neglect in terms of the distinctive separation in the capitalist mode of production between (a) the profit-oriented, market-mediated logic of capital accumulation and (b) the bourgeois-democratic, politically-mediated logic of national-popular hegemony that characterized a relatively autonomous sphere of political struggle. In this context, he added that capital accumulation followed its own logic of economic exploitation, valorization, and realization under the dominance of market forces without the need for any direct intervention into the labour process through coercion or other extraeconomic means. He concluded that this also enabled the state to be analysed as another relatively autonomous region within the overall matrix of the capitalist mode of production. Moreover, to arrive as quickly as possible at an autonomous science of the political (a scientific and practical goal that he shared with Antonio Gramsci), ${ }^{4}$ Poulantzas confessed that "certain key concepts of historical materialism do not get covered adequately because the focus is on the necessary order of exposition of a text bearing on the regional theory of the political" (1973: 24).

Step by step, however, culminating in State, power, socialism, Poulantzas moved from this exaggerated and misleading structuralist account of the mutual relative autonomies of the market economy and the constitutional state to a highly innovative account of capitalist relations of production and the state's role in their constitution and expanded reproduction. He came to argue that the social relations of capitalist production were inherently economic, political, and ideological (1978a,b). However, this was not due to the structural interpenetration in capitalist social formations of three "relatively autonomous" economic, political, and ideological regions - the position that he had maintained in Political power and social classes and that seems to have survived in one form or another until he wrote his final book. This presence of these structuralist residues in his work until State, power, socialism (1978a) reflected an ambiguity in the meanings of economics, politics, and ideology - which could be seen as structured ensembles of institutionally embedded practices or as different moments of a wide range social relations dispersed across a social formation (cf. Théret 1992). Moving away from the former position to the latter, Poulantzas now grounded his argument in the fact that the "social relations of production, exploitation, and extraction of surplus-value" had their own distinctive political and ideological moments as well as an obvious economic moment. While the last-mentioned moment was constituted through the differential distribution of the economic class powers

\footnotetext{
${ }^{3}$ Poulantzas committed suicide in November 1979, so events thereafter are irrelevant to this story.

${ }^{4}$ On Gramsci's wish to develop an autonomous science of the political (derived in turn from Machiavelli's discourse on The Prince), see Gramsci, 1971: 136-143.
} 
of ownership and possession, Poulantzas also identified a political moment that is grounded in relations of authority within the labour process (e.g., factory despotism, bureaucratization) and an ideological moment grounded in the division between manual and mental labour within the labour process and its implications for subjectivation (assujettissement) and lived experience in the economic region. This approach also opened theoretical space for thinking about the economic, political, and ideological moments of other sets of social relations, such as the state apparatus and exercise of state power.

This approach is far removed from the usual Marxist hierarchical model of an economic base, a corresponding juridico-political order that provides legal guarantees and political support to the profitoriented, market-mediated economy, and an even more remote superstructure comprising ideology and other forms of consciousness, with both the juridico-political and ideological levels nonetheless reacting back on the economic base. For, in contrast to this traditional topographic model with its economistic treatment of the economy, Poulantzas's new approach reveals "capitalist relations of production in all their complexity" (1978b: 115-116, italics in original). Along with his more advanced analysis of the social division of labour and his growing interest in the differential articulation of different types of economic space (e.g. 1978b: 117; and, especially, 1978a), this provided a possible route towards a partial reconciliation with Foucault, a theorist whose substantive analyses of power he appreciated even as he rejected many of their metatheoretical assumptions. Indeed, as Richard Marsden remarks in an interesting comparison of the two master thinkers:

Marx explains "why", that is, he describes the imperative of the social structure that facilitates and constrains social action, but he does not explain "how", the mechanics of capital's motion. Foucault explains "how", that is, he describes the mechanism of power, but he does not explain "why", the motive or purpose of disciplinary power. (Marsden 1999: 135)

Poulantzas's new approach permits a very different view of class powers with a great, if unrealized, potential to resolve several major problems in class analysis:

1. It indicates that economic, political, and ideological class powers are all present inside the social relations of production, exploitation, and surplus-value extraction rather than being distributed separately across three distinct levels or regions of a social formation. This overcomes the problem that he faced in Political power and social classes - and failed to resolve satisfactorily - of trying to define social classes in terms of their simultaneous location within three distinct but interrelated (hence "relatively autonomous") economic, political, and ideological regions. Social classes can now be defined in terms of complex class powers exercised within the labour process and the circuit of capital and their articulation with other forms of production.

2. This enables a careful analysis of how these complex class powers are supported through biases or asymmetries inscribed in the institutional materiality of the juridico-political and/or ideological spheres and through the differential effects of the extra-economic powers that are exercised in these other domains. While the exercise of such powers has a definite class relevance because of their differential impact on the expanded reproduction of the social relations of production, exploitation, and surplus-value extraction, these powers are typically marked, as Poulantzas noted for the normal capitalist type of state (liberal bourgeois democracy), by the constitutive absence of class from their formal institutional matrix. This disjunction creates distinctive fields and forms of political and ideological class struggle to secure the conditions for political and ideological as well as economic class domination. Each of these fields and forms of struggle has its own logics that reflect the formdetermined institutional materialities of their respective spheres and their interrelations with each other and the social relations of production (cf. Marx, Capital volume III: 791). Gramsci's analyses are especially resonant here because they address the problem of struggles for hegemony, the formation of power blocs, the mobilization of supporting classes, the relevance of social categories such as bureaucrats and intellectuals, and so forth (see Gramsci 1971, passim). 
3. Another crucial field of inquiry that opens here concerns the forms in which social classes are present, if at all, in the fields of political and ideological struggle as well as the effects of their absence. Poulantzas argued from the mid-1960s onwards that social classes were not directly represented as such in the political and ideological spheres and that an enormous effort was required to organize the changing balance of social forces to secure class interests in changing conjunctures. For example, as he noted in Political power and social classes, the exercise of the techno-economic, narrowly juridicopolitical, and ideological functions of the capitalist type of state was typically constrained by the overall political imperative of maintaining social cohesion in a class-divided society. This is reflected in the desirability, if not straightforward political imperative, for the various fractions of the power bloc to make short-term economic sacrifices to secure long-term political class domination. There are many examples of Poulantzas's recognition of these complexities in the field of political and ideological class struggle - both in his general theoretical studies, which drew on careful reading of the Marxist classics, and in his historical studies of fascism, military dictatorships, and authoritarian statism. This highlights the importance of developing appropriate strategic as well as structural concepts for the analysis of class powers, class domination, and class hegemony and, a fortiori, for the disjunctions, uneven development, and contradictions within and across different fields of struggle. This explains why he described some of his work as employing applied strategic concepts rather than concepts derived from a more abstract-formal analysis of the economic and political regions (Poulantzas 1975: 24ff).

4. This new approach also offers the means to avoid class reductionist analyses of the political and ideological regions. For it is no longer necessary to argue for the immediate structural determination of class relations by the repressive and/ideological state apparatuses or for an unmediated presence/absence of economic classes inside such apparatuses. On the latter point, it is enough to calculate the class-relevance of the overall structure of the political region, the balance of forces inside the state, and the balance of forces at a distance from the state and its implications for the exercise of state power. This is coherent with Poulantzas's innovative claim that the state is a social relation or, less elliptically, that state power is a form-determined material condensation of the balance of (class) forces in struggle. Thus, rather than looking for immediate correlations across different fields of social organization, this relational approach opens space to analyse disjunctions and uneven development as well as the presence and actions of specific social categories (e.g., bureaucrats or intellectuals) located in these domains.

5. Another set of issues that can be explored in these terms are the limits to state interventions that are intended to challenge the capitalist character of the social relations of production, whatever the prevailing balance of political forces. For these limits are rooted in (a) the separation of market economy and the state apparatus and, especially, (b) in the exclusion of the state, as Poulantzas recognized, from the heart of the organization of production.

This approach is far more consistent with Poulantzas's emphasis on (a) the state's variable presence in the constitution and expanded reproduction of the relations of production and (b) its incarnation par excellence of the manual-mental division of labour. It is also far more consistent with his distinctive analysis of the state's role, partly mediated by struggles for hegemony conducted in and through the capitalist type of state, in organizing the dominant classes into a power bloc as well as disorganizing the subordinate classes (see especially Poulantzas 1973: 29-32, 226-7, 284-289, 310-14; 1978a: 132-135, 140-5, 169-79, 213-19).

Before moving to political ecology, I briefly note some problems with Poulantzas's analysis of class powers and the dynamic of contemporary capitalism. These comprise: (a) the weakness of his analysis of economic crisis-tendencies, which owes too much to the over-simplified laws of overaccumulationdevalorization derived from the work of Paul Boccara and his colleagues in the French Communist Party or to a basic tendency of the rate of profit to fall derived from Capital volume III; ${ }^{5}$ (b) the grounding of his

\footnotetext{
${ }^{5}$ One result of this was an inability to deal with the specific features of financial crises - already noted in Capital III; and the specific features of ecological crises and their overdetermination by the logic of capital accumulation.
} 
analysis of contemporary capitalism in the features of Atlantic Fordism during the period of its expansion and initial crisis - which allowed Poulantzas to rethink imperialism, the comprador and national bourgeoisies, and the significance of the interior bourgeoisie, but limited his ability to think beyond Atlantic Fordism and its crises-tendencies to potentially new stages and/or varieties of capitalism as they had begun to emerge within the overall context of a rapidly changing world market; and (c) the continuing "methodological nationalism" of Poulantzas's analysis of the state even in the face of his growing recognition of the transnationalization of capitalist relations of ownership, possession, exploitation, and realization (for a more extended critique, see Jessop 2002). I conclude this section by bending the stick back in its rightful direction through noting that Poulantzas's contributions in other areas remain sadly under-recognized. These include his innovative work in relation to the nation, spatio-temporality, the politics of memory, and the mentalmanual division of labour.

\section{Poulantzas on nature and political ecology}

It is not the unity of living and active humanity with the natural, inorganic conditions of their metabolic exchange with nature, and hence their appropriation of nature, which requires explanation or is the result of a historic process, but rather the separation between these inorganic conditions of human existence and this active existence, a separation which is completely posited only in the relation of wage labour and capital (Marx, 1973: 489).

Poulantzas was an innovative thinker in many respects; in others, as one might expect from the uneven development of intellectual life, he was very much part of his epoch. He was writing when Fordism was still the dominant metropolitan accumulation regime. This regime is one that, if supported by an appropriate mode of regulation, involves a virtuous circle of growing mass production and matching increases in mass consumption in privileged regions. It was also underpinned, thanks to imperialism and its control of strategic resources, by a continuing decline in real oil prices as its critical input. The Fordist growth model was reflected in widespread neglect of the complex, organic relations between humankind and the natural environment and in optimism about the capacity of technological progress to resolve environmental problems. In addition, during this period, Poulantzas's main theoretical concerns were class relations, the specificity of the capitalist state and hegemonic struggles, and the distinction between normal and exceptional regimes. His analyses of economic crises were primarily based on the assumption of a generic crisis tendency that took the form of the tendency of the rate of profit to fall, which was grounded in the competitive logic of profit-producing capital, and the importance of mobilizing counter-tendencies thereto where they were not automatic. He did not mention ecological factors in crisis dynamics, let alone their fundamental organic link in contemporary societies to the logic of capital accumulation.

Likewise, his primary political concerns were Greek and French politics, where the green politics had at best a secondary role on the political scene up to the time of his death (on the French case, see Whiteside 2002). ${ }^{6}$ Thus, his references to the environment in this context were almost wholly confined to environmental movements, which he treated as operating, like the women's and students' movements, on secondary fronts in the class struggle (cf. 1978b). It is hardly surprising, then, that he ignored the implications of capital's distinctive metabolic interaction with nature. How times change. During the mid-1970s, with the crisis of Fordism and the first and second oil shocks, the environmental limits to continuing capital accumulation in advanced capitalist economies were just becoming self-evident. Today, it is virtually impossible, even for the Bush Administration [in office when this lecture was delivered] to ignore how the environment has acquired a primary role in economic, political, and ideological struggles as well as the importance of achieving an adequate understanding of the organic relations between capitalism and nature.

\footnotetext{
${ }^{6}$ While supporters of the environmental movement stood in local, regional, and national elections in the 1970s, a green political party (les verts) was not formed in France until 1982, three years after Poulantzas committed suicide. In Greece, a green party did not form until the late 1980s.
} 
Conjunctural issues apart, while there has recently been a path-breaking recovery of the wide-ranging and systematic concern of Marx (and Engels) with the natural conditions of wealth production alongside the contributions of labour-power and their implications for the destructive logic of capital accumulation (see especially Burkett 1999; Foster 2000), the neglect of political ecology in the critique of political economy has been a marked feature of the historical materialist tradition for some 120 years. Among the reasons for this, varying across periods and/or cases, are:

- Rejection of Malthusian pessimism about the demographic limits to growth;

- Rejection of social Darwinism with its apparent biological determinism;

- Belief in capitalism's progressive role in developing the productive forces in preparation for a transition to socialism and then communism;

- A focus on the internal contradictions of capitalism rather than on the external limits to continued accumulation; ${ }^{7}$

- The focus of Marxist political economy on what separates capitalism from pre-capitalist modes of production - the appropriation and transformation of nature being, in contrast, a feature of "production in general";

- A relative neglect of the use-value dimensions of generalized commodity production in order to concentrate on the distinctive features of exchange-value in the capitalist logic of valorization; and

- Denial of the damage being done in Stalinist industrialization to catch up with advanced capitalism. ${ }^{8}$

In sum, lack of interest was common among Poulantzas's Marxist contemporaries. In addition, Poulantzas himself was fighting a deliberate battle against technological determinism - he argued forcefully for the primacy of the social relations of production over the forces of production. This encouraged neglect of raw nature as a source of wealth and as a force of production. Later, he would admit that, in focusing his attack on economism, he had bent the stick in the other direction, i.e., towards politicism (1978a: 51-2). But he never recognized that, in so doing, he had bent the stick even further away from engaging with ecological issues. Thus, nowhere did he refer to the importance of first nature or its transformation through social practices into second nature. Moreover, apart from some occasional remarks on the environmental damage done by state socialism in the Soviet bloc because of its excessive focus on technological development, the environment is fully absent from his theoretical and political horizons.

Does this mean that Poulantzas, who was always sensitive to changing theoretical conjunctures without being a dedicated follower of every theoretical fashion - would have had nothing to say in the face of increasing concern with environmental issues and political ecology? And does it mean that, while he was sensitive to contemporary strategic issues, he would not have integrated political ecological concerns into his views of democratic socialism? One could respond that these are unanswerable hypothetical questions. But it is still worth reflecting upon what a strategic-relational reading of the kind presented in Poulantzas's final studies might contribute to these questions. This does not mean putting words directly into his mouth but simply involves rational speculation about the implications of his approach for a critical political ecology. In this spirit, then, I make five suggestions:

1. Poulantzas would have rejected both eco- and anthropo-centric accounts of the relation between nature and the human species in favour of a critical, historicized, relational account of the forms of nature and humanity and, of course, their changing articulation. This follows from (a) his historical, relational analysis of the individual (and individualization), the nation, space, time, and other social categories and (b) his lasting concern with the overdetermination of such categories by class relations

\footnotetext{
${ }^{7}$ Deléage (1994: 47, cited by Whiteside 2002: 190). Cf. O'Connor on neglect of the "second contradiction" of capitalism.

${ }^{8}$ Benton (1996: 83-83) lists this as one of the reasons why green thinkers feel allergic to Marxism.
} 
(e.g., 1973, 1978a). It also reflects Marx's own insistence on the historical specificity of how natural conditions are articulated with social relations of production and their subsequent co-evolution (cf. Burkett 1999: passim). Moreover, given my earlier remarks on Poulantzas's acute recognition of the significance of the separation of the economic and the political regions of the capitalist mode of production and/or of capitalist social formations, he would probably have been equally sensitive to the disjunction introduced between the natural conditions of production and the value form of wealth, considered as an "immense accumulation of commodities", in which many natural conditions are disregarded (and, indeed, seriously harmed, if not destroyed) because they have no "value" from a capitalist viewpoint. On the other hand, he would probably not have attempted to explain contemporary "first nature" or "second nature" purely in terms of the logic of capital accumulation ${ }^{9}$, having asserted that "capitalism is not the source of all evil" (1978a: 24, 207) and having reflected on the problems of the bureaucratic deformation of state socialism during its drive for industrialization.

2. Poulantzas would nonetheless have insisted on analysing the appropriation and transformation of nature as well as the natural limits to the expanded reproduction of capital in relational terms, i.e., in terms of a class analysis of environmental issues. He would have critiqued productivism (the celebration of production for the sake of production, tied to the creation of new use-values in order to realize surplus-value) as an effect of the treadmill of capital accumulation; and he would have linked this to uneven development, to the dynamic of inter-imperialist rivalries, and to the phenomena of imperialism. Moreover, while recognizing the increasingly general impact of some aspects of ecological pollution, depletion of renewable resources, and disruption of natural systems, he would also have noted that their impact was not uniform and that responses to these challenges were conditioned in part by divisions among the dominant classes, inter-imperialist competition and rivalries, dependency relations within the world market, and conflicts among the popular masses. In this sense, then, he would not have abandoned class analysis (unlike André Gorz bidding farewell to the working class) but would probably have agreed with Michel Löwy, who was his assistant at the Université de Paris 8-Vincennes from 1969-77, ${ }^{10}$ that

The ecological issue is ...the great challenge for a renewal of Marxist thought at the threshold of the 21st century. It requires that Marxists undertake a deep critical revision of their traditional conception of "productive forces," and that they break radically with the ideology of linear progress and with the technological and economic paradigm of modern industrial civilization. ... Ecologists are mistaken if they imagine they can do without the Marxian critique of capitalism (2005: 15, 17).

Nor would he have stopped with recognizing the continued importance of the historically specific form of capitalist relations of production, their role in the development of the forces of production, and their impact on the forms of wealth production and transformation of nature. He would have tied this, as noted, to the analysis of class powers and, especially, to an account of the state's role in mediating and guiding responses to ecological problems.

3. Thus, Poulantzas would have paid special attention to (a) conflicts within and across different national and transnational capitalist fractions and (b) the tensions inherent in the co-existence of a tendentially ever-more integrated world market with the globalization of ecological crisis-tendencies and the continued existence of a plurality of national states. Indeed, as he emphasized, "neither within capital as a whole nor within monopoly capital itself, is there an instance capable of laying down who should make sacrifices so that others may continue to prosper" (1978a: 182-183). This results in contradictions that traverse the networks and branches of the state economic apparatus in their entirety (1978a: 171) and leads to decisions favourable to the economic interests of capital that may well prove

\footnotetext{
${ }^{9}$ This argument, which is grounded in Poulantzas's own approach to similar questions, is also consistent with the French intellectual tradition, with its concern with "how nature and humanity are mutually defining" (Whitehead 2002: 4, citing the French political ecologist, Moscovici [1974] on Marx's recognition that man is part of nature).

${ }^{10}$ On this period, see Löwy (2015).
} 
incompatible with the maintenance of hegemony, the more so as all state policies and practices are being reorganized around economic imperatives (1978a: 167-169).

4. It is in regard to the state that I would expect Poulantzas to have made his most significant contribution to political ecology. Specifically, he would have analysed the changing boundaries and changing scope of the economic and extra-economic spheres as the ecological crisis begins to impact accumulation strategies and modes of regulation and/or to move ecological issues from the margins of life to the heart of contemporary politics. This in turn would be reflected in his analysis of the changing techno-economic-ecological functions of the state as well as their continuing subordination to its generic function of maintaining social cohesion in a class-divided society. It would also be reflected in his discussion of the growing trend towards authoritarian statism insofar as the requirements of ecological, strategic resource, economic, and, above all, bio-security are likely to reinforce the generic crisis tendencies of capitalism and to intensify political struggles within and among national states. These claims are grounded above all in the analysis of the state and the economy in State, power, socialism (1978a), which is extremely sensitive to the variability of the articulation between the economic and political spheres and the increasing politicization of the economy and economization of the political. Poulantzas would have analysed how disputes over environmental policy and issues of political ecological governance more generally are shot through with disputes within and among fractions of capital, intensifying cracks in the power bloc (1978a: 212-213). The impact of ecological crisis would also have repercussions on other classes and social categories, leading to the politicization of ecological issues and their movement from "secondary fronts" to a central place in the overall articulation of politics. More generally, once the state comes into being, it transforms all it touches (including, by implication, the "state of nature", which becomes politicized "nature of the state") (1978a).

5. Poulantzas would have integrated a Marxist critique of political ecology into his strategy for a democratic transition to democratic socialism. The social movements that he saw as key flanking and supporting forces in the socialist project included environmental groups, the anti-nuclear movement, feminism, and so on. He acknowledges already in State, power, socialism that:

the objective field of popular alliances is undergoing considerable expansion. In addition, conflicts more closely bound up with the ideological crisis appear as both the origin and the effect of a new popular awareness concerning questions that are now no longer "secondary" fronts - witness, in this regard, the student movement, the women's liberation movement and the ecological movement (1978a: 211).

Contemporary French environmentalists, with rare exceptions, tended to be localist and piecemeal in orientation, perhaps justifying Poulantzas's treatment of them as having secondary significance. However, the more recent expansion of green movements and green parties to become an independent political force at the national and, indeed, international level must change this calculation. But it would still involve linking the critique of political ecology with that of political economy, showing the organic connection between the capitalist form of wealth production as an immense accumulation of commodities and the specific dynamic and forms of the ecological crisis in individual capitalist social formations, the world market, and an increasingly global village.

\section{Democratic Socialism}

Poulantzas refused to present a general model for a transitional state. As he noted:

A "model" of the State of transition to socialism cannot be drawn up: not as a universal model capable of being concretized in given cases, nor even as an infallible, theoretically guaranteed recipe for one or several countries (1978a: 22). 
Nonetheless, his overall strategic recommendations for a democratic transition to democratic socialism comprised a threefold combination of struggles within the state to modify the balance of forces, struggles to transform the state to make it more accessible to popular forces and to weaken the structurally-inscribed selectivities of the existing state apparatus, and struggles at a distance from the state to modify the internal balance of forces and polarize them towards a radical transformation. In addition, he offered specific recommendations about the appropriate form of state for democratic socialism - one based on a judicious combination of direct democracy and representative democracy in which the economic and political logic of each moderated the tendencies towards failure of the other. Indeed, Poulantzas emphasized the "irreducible tension" between direct democracy and representative democracy (1978b: 177, italics in original; cf. 1978a).

Thus, as he noted elsewhere, direct democracy runs the risk of factory [or enterprise] egoism and parochialism and could also fail because of limited resources and lack of support from the centre; similarly, both organized labour movements as well as social movements without ties to organized labour run in equal measure the risk of being absorbed into the networks of the state. ${ }^{11}$ Conversely, a purely representative democracy runs the risk of deepening the separation of the representatives and represented and being insensitive to local needs. The dual solution that Poulantzas called for was (a) the democratization of the state and its representative organs so that it would be more open to pressures from below and at a distance from it, and also more ready to support them in their own struggles and (b) the development of what I choose to call maximum feasible solidarity among local-regional and single- or limited-issue movements so that the problems of parochialism, localism, and egoism can be limited within the pursuit of an overall vision of democratic socialism.

These ideas can be expressed in systems-theoretical terms through the ideas of "requisite variety" and "necessary reflexivity". First, if no mode of economic and political organization provides an optimal means of economic and political governance, because of the inherent selectivities involved in each and because of their associated crisis-tendencies and typical forms of failure, then it makes sense to combine several modes that can be deployed with their weight varying according to the relative extent, intensity, and urgency of specific problems. Poulantzas's arguments for combining direct and representative democracy, especially if combined with a multi-scalar approach to democratic governance, appear to be consistent with this perspective. Second, if there is no fool-proof, inherently successful mode of representation and governance, then it is essential to promote foresight, reflexivity, and feedback on potential and emerging problems and their provisional solutions.

But requisite variety and reflexivity are insufficient. For, if there are no guarantees of success and some measure of failure is inevitable, something more is required. Poulantzas was certainly aware of the risks of revolutionary action, even when it proved successful in the first instance. For he had condemned the bureaucratic deformation of the Russian revolution; criticized the failure of the democratic transition in Portugal; and warned about the limits to social democracy. But this did not lead him to advocate an immediate move to armed struggle. He was a strong believer in conjunctural analysis and in identifying the horizons of possibility in advancing the cause of democratic socialism in particular times and places. Thus, in State, power, socialism, Poulantzas not only criticized the social democratic belief in a gradual, irreversible, and cumulative movement to democratic socialism but also cautioned strongly against regarding violent onslaught on the state as a genuine alternative to a democratic transition to democratic socialism. One way to think about this is in terms of the inherent limits to revolutionary mobilization and the risks of failure. If these risks are high, then it is better to engage in a double form of irony. The first form is familiar from the wellknown aphorism that Gramsci placed on the masthead of L'Ordine Nuovo: "pessimism of the intellect, optimism of the will." This translates in the present context into the need to recognize the risks of failure, but to act as if you can succeed. Yet, as Poulantzas noted, there is no "theoretically guaranteed recipe" for success. So, the second form of irony is to reflect that, if one cannot guarantee success, one can at least choose one's mode of likely failure. And, if so, one must choose wisely. I believe that Poulantzas faced up to both dilemmas and quite consciously argued in State, power, socialism that it was better to choose the risk of

\footnotetext{
${ }^{11}$ See Poulantzas (1978b: 176), in relation to Ingrao's strategy for social movements; and ibid, pp. 180 and 182 on the risks of corporatism.
} 
a democratic failure to make a democratic transition to democratic socialism than to risk the consequences of opting for a bloody failure to make a violent transition to an unknown socialism. But in opting for the path of democratic failure, he also aimed to minimize the chances of democratic failure through his recommendations about the form that such a democratic path should take. For this should combine direct and representative democracy, class and cross-class mobilization, political parties and social movements, in an unstable mix oriented to maintaining an unstable equilibrium of compromise.

\section{Conclusions}

We live in an epoch and conjuncture that is radically different in crucial respects from that in which Poulantzas lived, reflected, and struggled. Nonetheless, his overall approach to critical political economy and, in particular, to the state and state power remains valid. But it cannot just be applied in the condition in which he left it. Alongside the work of mourning we must put the work of renewal. This involves continuing the unfinished work of a basic theoretical revolution in Marxist analyses of the state and disentangling arguments specific to particular conjunctures and national cases from those that have a more general validity for a historical period or for the logic of capital accumulation and state intervention considered as a whole. We should approach this task in the same critical spirit as Poulantzas tackled his own studies as well as those of others: to appreciate its significant theoretical ruptures, to fill its gaps, to assess its relevance to new problems and theoretical currents, to develop it in new directions. But we should also try to avoid that theoreticism that deforms and stultifies so much Marxist analysis and aim instead to link theoretical analysis with issues of political strategy. Poulantzas himself fought long and hard for left unity in France and Greece and tried to provide the theoretical foundations for an effective strategy oriented to a democratic transition to democratic socialism under the conditions of contemporary capitalism. This was certainly a struggle worth fighting and it is even more important today than ever that this struggle is continued and intensified.

\section{References}

Anderson, P. 1976. Considerations on western Marxism. London: New Left Books.

Benton, T. 1996. The greening of Marxism. New York: Guilford Press.

Burkett, P. 1999. Marx and nature: a Red and Green perspective. New York: St Martinhs Press.

Deléage, J.-P. 1994 Eco-Marxist critique of political economy. In M. O'Connor (ed.). Is capitalism sustainable? New York: Guilford Press. Pp. 37-52.

Foster, J.B. 2000. Marx's ecology: materialism and nature. New York: Monthly Review Press.

Gorz, A. 1980[1975]. Ecology as politics. Montreal: South End Press.

Gramsci, A. 1971. Selections from the Prison Notebooks. London: Lawrence \& Wishart.

Jessop, B. 1985. Nicos Poulantzas: Marxist theory and political strategy. London: Macmillan.

Jessop, B. 2002. Globalization and the national state. In S. Aronowitz and P. Bratsis (eds.) Paradigm lost: state theory reconsidered. Minneapolis: University of Minnesota Press. Pp. 185-220.

Jessop, B. 2017. Poulantzas zum Imperialismus. In T. Boos, H. Lichtenberger, and A. Puller (eds.). Mit Poulantzas arbeiten, um aktuelle Macht- und Herrschaftsverhältnisse zu verstehen. Hamburg: VSA.

Lipietz, A. 1994. Green hopes: the foundations of political ecology. Cambridge: Polity.

Löwy, M. 2005. What is ecosocialism? Capitalism, Nature, Socialism 16(2): 15-24.

Löwy, M. 2015. Michael Löwy: the Nicos Poulantzas I knew (interview). URL: http://www.versobooks.com/blogs/1908-michael-lowy-the-nicos-poulantzas-i-knew.

Luhmann, N. 1982 The differentiation of society. New York: Columbia University Press.

Marsden, R. 1999. The nature of capital: Marx after Foucault. London: Routledge.

Marx, K. 1967[1894]. Capital, volume III. London: Lawrence \& Wishart.

Marx, K. 1973[1857-1858]. Grundrisse. Harmondsworth: Penguin.

Moscovici, S. 1974. Hommes domestiques et hommes sauvages. Paris: Christian Bourgeois.

O'Connor, J. 1998. Natural causes: essays on ecological Marxism. New York: Guildford Press. 
Poulantzas, N. 1973[1968]. Political power and social classes. London: New Left Books.

Poulantzas, N. 1974[1970]. Fascism and dictatorship. London: New Left Books.

Poulantzas, N. 1974. The internationalization of capital and the nation state. Economy and Society 3(2): 145179.

Poulantzas, N. 1975[1974]. Classes in contemporary capitalism. London: New Left Books.

Poulantzas, N. 1976. Crisis of the dictatorships. London: New Left Books.

Poulantzas, N. (ed.). 1976. La crise de l'état. Paris: Presses Universitaires de France.

Poulantzas, N. 1978a. State, power, socialism. London: Verso.

Poulantzas, N. 1978b. Repères. Paris: Maspero.

Sarkar, S. 1999. Eco-socialism or eco-capitalism? A critical analysis of humanity's fundamental choices. London: Zed Books.

Théret, B. 1992. Régimes économiques de l'ordre politique. Esquisse d'une théorie régulationniste des limites de l'État. Paris: Presses Universitaires de France.

Whiteside, K.H. 2002. Divided natures: French contributions to political ecology. Cambridge: MIT Press. 